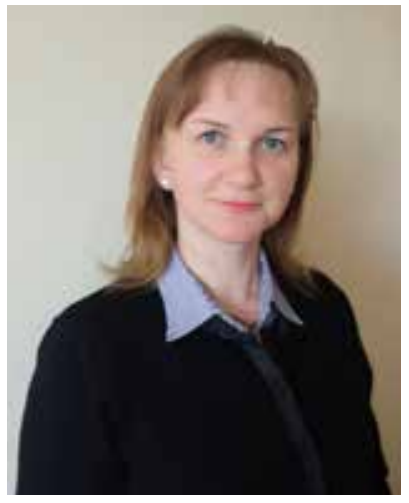

Олена Максименко,

кандиьат юридичних наук, старший науковий співробітник,

старший науковий співробітник наукової ^абораторії

з проблем протиАії злочинності

Навчально-наукового інституту № 1

Національної акамемії внутрішніх справ

https://orcid.org/0000-0002-3039-1773

https://doi.org/10.32782/2020-38-04

УдК 342.9

\title{
Дитина як спеціальний суб'єкт адміністративного права у процесі реалізації ювенальної політики України
}

Постановка проблеми. Актуальність теми зумовлена тим, що із розвитком науки адміністративного права України останнім часом дуже мало уваги науковців приділяється дослідженням фундаментальних явищ. Перехід від державоцентристських до людиноцентристських пріоритетів у адміністративному праві виділяє людину понад усе i дитину як людську істоту [1]. Реалізація ювенальної політики в Україні спонукає державу до запровадження новітніх способів задоволення інтересів дітей із обов'язковим урахуванням забезпечення їхніх найкращих інтересів крізь надбання сучасної правової науки, яка здатна виробити та обгрунтувати концептуальні та практичні засади взаємин дитини та держави. Тому системного аналізу потребує адміністративне законодавство України з питань трансформації взаємин між дитиною та органами державної влади 3 метою вироблення нових наукових підходів.

Відповідно до статті 1 Конвенції ООН «Про права дитини» дитиною визнано кожну людську істоту до досягнення 18-річного віку, якщо за законом, застосовуваним до такої особи, вона не досягає повноліття раніше [2].

Політика держави, що спрямована на захист прав дитини, боротьбу iз дитячою бездоглядністю та профілактикою злочинів і правопорушень у дитячому середовищі, часто є малоефективною. Усе частіше у засобах масової інформації фігурують повідомлення про скоєння правопорушень дітьми та стосовно них. Тому розділяємо позицію Р.М. Опацького, який розглядає ювенальну політику як частину внутрішньої політики української держави, особливий вид соціальної діяльності, врегульований нормами міжнародного та національного права, спрямований на ефективне забезпечення прав і законних інтересів неповнолітніх. Така політика повинна відображати як загальні інтереси, потреби і права всіх без винятку осіб до 18 років, так і блага різних соціальних і вікових груп неповнолітніх [3].

Розбудова ювенальної політики в Україні має бути ефективним 
інструментом забезпечення, реалізації та охорони прав дітей. Назріла потреба розглянути дитину як спеціальний суб'єкт адміністративного права в процесі реалізації ювенальної політики України та переосмислення дитини як громадянина держави, як члена сім'ї, як самостійного індивіда у взаємодії з державними органами.

Аналіз останніх досліджень і публікацій. Над проблемами науки адміністративного права загалом працювали та працюють багато провідних науковців. Відомі роботи таких українських та закордонних учених, як: В.Б. Авер'янов, О.М. Бандурка, М.В. Банчук, Д.М. Бахрах, В.М. Бевзенко, А.І. Берлач, С.Г. Братель, М.Ю. Віхляєв, Т.О. Гуржій, І.П. Голосніченко, С.К. Гречанюк, А.О. Галай, Є.В. Додін, Р.А. Калюжний, Л.В. Коваль, І.Б. Коліушко, Т.О. Коломоєць, В.К. Колпаков, С.Ф. Костантінов, А.Т. Комзюк, О.В. Кузьменко, К.Б. Левченко, Д.М. Лук'янець, Т.О. Мацелик, Р.С. Мельник, Н.С. Нижник, В.І. Олефір, С.В. Пєтков, О.П. Рябченко, А.О. Селіванов, А.О. Собакарь, Ю.М. Старилов, Р.О. Стефанчук, С.Г. Стеценко, С.М. Тимченко, Ю.А. Тихомиров, О.Н. Ярмиш та ін. Водночас наукового аналізу дитини як спеціального суб'єкта адміністративного права в процесі реалізації ювенальної політики не було, а отже, є потреба в подальших наукових дослідженнях.

Залишається недослідженим спеціальний суб'єкт адміністративного права в процесі реалізації ювенальної політики України - дитина (фізична особа до 18 років). Метою статті $€$ дослідження статусу дитини як спеціального суб'єкта адміністративного права України в процесі реалізації ювенальної політики.

Виклад основного матеріалу. Розвиток адміністративно-правової науки дає нам можливість розглянути адміністративне право України як самостійну галузь права, якій притаманні всі відповідні складники. Так, поділяючи погляди науковців, визначимо, що адміністративне право України - це сукупність правових норм, які регулюють суспільні відносини, що формуються під час забезпечення органами виконавчої влади й органами місцевого самоврядування реалізації та захисту прав, свобод і законних інтересів фізичних і юридичних осіб, а також у процесі публічного адміністрування в сферах соціально-економічного й адміністративно-політичного розвитку та охорони громадського порядку [4, с. 3].

Одними із найважливіших складників адміністративного права України є суб'єкти. Під суб'єктами адміністративного права варто розуміти юридичну чи фізичну особу, що $є$ носієм прав і обов'язків у сфері державного управління, передбачених адміністративно-правовими нормами, та має здатність надані права реалізовувати, а покладені обов'язки виконувати. Обов'язковою умовою визнання особи (юридичної чи фізичної) суб'єктом адміністративного права $є$ наявність у неї елементів адміністративної правосуб'єктності. Більшість джерел вказує на виділення таких елементів правосуб'єктності, як правоздатність та дієздатність. Вважаємо, що в адміністративному праві України варто розглядати правосуб'єктність із елементами правоздатності, дієздатності та деліктоздатності.

Суб'єктом адміністративного права є фізична особа, а тому можемо розглянути і дитину як суб'єкта адміністративного права 3 елементами правосуб'єктності: адміністративною правоздатністю, дієздатністю та деліктоздатністю.

Адміністративна правоздатність при цьому розуміється як здатність бути носієм прав і обов'язків у сфері державного управління i виникає в громадян 3 моменту народження й припиняється з їхньою смертю (наприклад, право бути зареєстрованим). 
Адміністративна дієздатність розуміється як здатність своїми діями здійснювати надані права, виконувати встановлені обов'язки й нести юридичну відповідальність за свою поведінку, наступає вона у фізичних осіб з досягненням певного віку [5]. Стосовно дитини вважаємо, що свою дієздатність вона може реалізувати через батьків або осіб, які їх заміняють, законних представників. У процесі реалізації ювенальної політики в Україні діти мають право та можливості звертатися самостійно в поліцію, службу у справах дітей, до Уповноваженого 3 прав дитини та інших органів державної влади за захистом своїх прав.

Адміністративна деліктоздатність, на нашу думку, - це здатність суб'єкта нести адміністративну відповідальність за скоєні адміністративні правопорушення. Вважаємо, що в адміністративному праві України особи віком від 16 до 18 років деліктоздатні (хоча вони ще не мають повної дієздатності, а можуть реалізувати здебільшого свої права через законних представників, лише деякі права самостійно).

Так, у статті 12 Кодексу України про адміністративні правопорушення (далі - КУпАП) зазначено, що адміністративній відповідальності підлягають особи, які досягли на момент вчинення адміністративного правопорушення шістнадцятирічного віку. За стандартних умов це є фізична осудна особа [6]. Зазначене дає підстави стверджувати, що дитина може бути спеціальним суб'єктом в адміністративному праві.

Автор дотримується позиції, що діти є спеиіальними суб'єктами в адміністративному праві Украӥни, тобто такими, які мають спеціальний статус: наділені адміністративними правами від народження, мають право реалізувати свої законні можливості через законних представників і здатні самостійно відповідати за свої протиправні вчинки після досягнення 16-річного віку. Згідно зі статтею 13 КУПАП України, до осіб віком 16-18 років, які вчинили адміністративні правопорушення, застосовуються відповідні заходи впливу, передбачені статтею 24-1 КУПАП: 1) зобов'язання публічно або в іншій формі попросити вибачення у потерпілого; 2) попередження; 3) догана або сувора догана; 4) передача неповнолітнього під нагляд батькам або особам, які їх замінюють, чи під нагляд педагогічному або трудовому колективу за їхньою згодою, а також окремим громадянам на їхне прохання.

Заходи впливу, передбачені цією статтею, не є адміністративними стягненнями в розумінні статті 23 цього Кодексу. Вони є альтернативними заходами виховного впливу, які можуть бути застосовані тоді, коли виховання неповнолітнього правопорушника $є$ можливим без накладення адміністративного стягнення у загальному порядку, передбаченому КУПАП. Водночас рішення про застосування цих заходів можна вважати одним з можливих наслідків урахування органом (посадовою особою), що вирішує справу про адмінправопорушення, такої пом'якшуючої обставини, яка враховується у разі вирішення питання про адміністративну відповідальність особи, як вчинення правопорушення неповнолітнім [7].

$\mathrm{y}$ разі вчинення особами віком від шістнадцяти до вісімнадцяти років адміністративних правопорушень, передбачених статтями 44, 51, 121-127, частинами першою, другою i третьою статті 130, статтею 139, частиною другою статті 156, статтями 173 , 174, 185, 190-195 цього Кодексу, вони підлягають адміністративній відповідальності на загальних підставах. 3 урахуванням характеру вчиненого правопорушення та особи правопорушника до зазначених осіб (за винятком осіб, які вчинили правопорушення, передбачені статтею 185) можуть бути 
застосовані заходи впливу, передбачені статтею 24 цього Кодексу. Однак застосування органом (посадовою особою), уповноваженим розглядати справи про зазначені адмінправопорушення, суб'єктом яких є неповнолітній, заходів впливу, передбачених статтею 24-1 цього Кодексу, є правом, а не обов'язком цього органу (посадової особи) [8].

Неповнолітні, які не досягли встановленого в законі віку 16 років, згідно з КУПАП України, є малолітніми і юридичній відповідальності, у тому числі адміністративній, не підлягають, оскільки визнаються нездатними усвідомлювати значення своїх дій і керувати ними. До того ж адміністративна відповідальність дитини може настати тільки тоді, коли 16 років їй виповнилось саме до моменту вчинення протиправного діяння, а не до вирішення питання про притягнення iㅣ до адміністративної відповідальності.

Законом визначено, що заходи впливу мають виховний характер i можуть бути застосовані до дітей, які скоїли адміністративний проступок, віком 16-18 років, якщо орган адміністративної юрисдикції дійде висновку, що виправлення правопорушника можливе без застосування до нього суворішого адміністративного стягнення. У сукупності ці заходи утворюють систему, що складена 3 урахуванням збільшення тяжкості примусових заходів - від менш суворих до суворіших.

Варто наголосити, що скоєння адміністративного проступку дитиною є обставиною, що пом'якшує її відповідальність. Пояснюється це тим, що неповнолітні загалом не мають стійкої психіки, навичок правочинної поведінки, достатнього життевого досвіду, не завжди усвідомлюють шкоду від заподіяного, легко піддаються впливу інших осіб, особливо старших за віком, що часто стають організаторами або підбурювачами правопорушень, ураховується також, що неповнолітні легко піддаються виховному впливу і можуть виправитись без застосування до них жорстких заходів адміністративного стягнення [8].

Згідно 3 положеннями Національної стратегії реформування системи юстиції щодо дітей на період до 2023 року, розпорядженням Кабінету Міністрів України від 18.12.2018 року № 1027, задля удосконалення та реалізації ювенальної політики держави в рамках міжнародних норм зазначено, що в Україні процедури притягнення до адміністративної відповідальності $є$ значною мірою застарілими у зв'язку з тим, що Кодекс України про адміністративні правопорушення прийнято Верховною Радою Української РСР 7 грудня 1984 року та введено в дію з 1 червня 1985 року. Українській правовій системі властиві проблеми, характерні для інших пострадянських держав: законодавче регулювання суспільних відносин не відповідає сучасній ситуації та не містить належних гарантій захисту прав осіб, передбачених міжнародними стандартами. Процедури провадження у справах про адміністративні правопорушення порівняно з кримінальними є спрощеними, а перелік засобів для захисту особи, яка притягується до адміністративної відповідальності, досить обмежений. Розгляд справ про адміністративні правопорушення часто формальний, a наявність протоколу про адміністративне правопорушення сприймається як беззаперечний доказ вини особи. Отже, деякі права осіб, які притягуються до адміністративної відповідальності, на важливості яких наголошується у міжнародних документах, не передбачені Кодексом України про адміністративні правопорушення. Проаналізувавши положення такої Стратегії та положення Кодексу України про адміністративні правопорушення, автор підтримує 
позицію щодо необхідності удосконалення процесу адміністративних проваджень за участю дітей.

3 метою удосконалення системи судочинства у частині притягнення неповнолітніх до відповідальності за вчинення адміністративних правопорушень необхідно:

1) забезпечити:

- дотримання принципу презумпції невинуватості особи;

- належне та своєчасне повідомлення батьків або законних представників неповнолітнього про його затримання;

- ефективний доступ неповнолітніх до безоплатної вторинної правової допомоги шляхом удосконалення механізму швидкого залучення захисника;

- спеціалізацію суддів, що розглядають справи про адміністративні правопорушення за участю неповнолітніх;

- дотримання принципу пропорційності призначеного адміністративного стягнення або заходу впливу вчиненому правопорушенню;

- дотримання принципу індивідуалізації відповідальності - скасування адміністративної відповідальності батьків за вчинення неповнолітніми віком від 14 до 16 років адміністративних правопорушень та діянь, що містять ознаки злочину, відповідальність за які передбачена Кримінальним кодексом України, якщо вони не досягли віку, з якого настає кримінальна відповідальність;

2) передбачити можливість звільнення неповнолітніх від відповідальності до розгляду справи судом 3 покладенням на них певних обов'язків (відвідування корекційних програм, закладу освіти тощо);

3) удосконалити положення Кодексу України про адміністративні правопорушення в частині захисту процесуальних прав неповнолітніх, що притягуються до адміністративної відповідальності, зокрема захисту їхнього права на конфіденційність, права неповнолітнього під час адміністративного затримання на утримування окремо від дорослих правопорушників, права особи, що притягується до адміністративної відповідальності, потерпілого, ї законного представника на заявлення відводів;

4) запровадити механізм заміни адміністративного стягнення у вигляді штрафу іншим видом стягнення для неповнолітніх осіб, які не мають самостійного джерела доходів [9].

Висновки. Підсумовуючи вищевикладене, слід зазначити, що положення Конвенції ООН «Про права дитини» дають можливість розглядати дитину як окрему людину, яка не досягла 18 років, але має можливість самостійно реалізовувати та захищати свої права, звертаючись до відповідних правозахисних органів та установ, посадових осіб, громадськості. Дитина, яка є громадянином України, відповідно до Закону «Про громадянство України» має правовий зв'язок із державою, що знаходить свій вияв у їхніх взаємних правах та обов'язках, які регламентуються законодавством України [10].

Проаналізувавши положення адміністративного права України, доходимо висновку, що дитину можемо вважати його суб'єктом. Саме на етапі розвитку держави, коли одним із засобів забезпечення прав і свобод дітей $є$ активне впровадження ювенальної політики.

Вважаємо, що дитина є суб'єктом адміністративного права як фізична осудна особа, яка $€$ носієм прав i обов’язків перед державою, а також до неї як до громадянина держава має низку прав та обов'язків. Права дитини охороняються нормами адміністративного законодавства України. Дитина може самостійно реалізовувати, захищати свої права, самостійно нести адміністративну відповідальність, а також реалізовувати свої права за допомогою батьків, осіб, які їх заміняють, чи 
законних представників. Держава має низку адміністративних зобов'язань перед дитиною:

- заяву про реєстрацію народження дитини батьки зобов'язані подати невідкладно, але не пізніше одного місяця 3 дня народження дитини, а у разі народження мертвої дитини - не пізніше трьох діб. Невиконання цього обов'язку є підставою для покладання на батьків дитини відповідальності, установленої законом. Органи державної влади наділені повноваженнями 3 виявлення i притягнення до відповідальності таких осіб [11];

- пакет документів, які необхідні для отримання паспорта громадянина
України вперше, безоплатно дитина має право подати не пізніше ніж через місяць після досягнення 14 років до територіального підрозділу Державної міграційної служби України за місцем проживання [12];

- держава надає соціальну допомогу дітям, які цього потребують, у встановленому законом порядку;

- дитина, яка досягла 16-річного віку, самостійно здатна нести відповідальність за порушення норм адміністративного права України.

Отже, розбудова ювенальної політики в Україні спрямована на захист прав та найкращих інтересів дітей, охороняється законодавством та покладає на дітей певні обов’язки.

\section{Список використаних джерел}

1. Окремі аспекти розвитку доктрини українського адміністративного права. URL: https://doi.org/10.26739/2181-9130-2018-1-2-2.https://search.crossref.org/?q=\%D 1\%81\%D1\%83\%D0\%B1\%D1\%8C\%D0\%B5\%D0\%BA\%D1\%82+\%D0\%B0\%D0\%B4\%D0\% BC\%D0\%B8\%D0\%BD\%D0\%B8\%D1\%81\%D1\%82\%D1\%80\%D0\%B0\%D1\%82\%D0\%B8\% D0\%B2\%D0\%BD\%D0\%BE\%D0\%B3\%D0\%BE+\%D0\%BF\%D1\%80\%D0\%B0\%D0\%B2\%D $0 \% \mathrm{~B} 0 \&$ page $=1$.

2. Конвенція ООН «Про права дитини». URL: https://zakon.rada.gov.ua/laws/ show/995_021\#Text.

3. Ювенальна політика: поняття та зміст. URL: http://pravoisuspilstvo.org.ua/ archive/2012/1 2012/09.pdf.

4. Адміністративне право України : підручник. Вид. 2, змін. і доп. / За заг. ред. Т.О. Коломоєць. Київ : Істина, 2012. 528 с.

5. Адміністративне право. URL: http://virtuni.education.zp.ua/edu_cpu/mod/ resource/view.php?id=17154.

6. Кодекс України про адміністративні правопорушення. URL: info/матеріал/ стаття-12-вік-після-досягнення-якого-настає-адміністративна-відповідальність.

7. Кодекс України про адміністративні правопорушення. URL: info/матеріал/ стаття-241-заходи-впливу-що-застосовуються-до-неповнолітніх.

8. Кодекс України про адміністративні правопорушення. URL: info/матеріал/ стаття-13-відповідальність-неповнолітніх.

9. Національна Стратегія. URL: https://zakon.rada.gov.ua/laws/show/1027-2018$\% \mathrm{D} 1 \% 80$ \# Text.

10. Закон України «Про громадянство України». URL: https://zakon.rada.gov.ua/ laws/show/2235-14\#Text.

11. Реєстрація народження. URL: https://mfa.gov.ua/konsulski-pitannya/ reyestraciya-aktiv-civilnogo-stanu/reyestraciya-narodzhennya.

12. Державна міграційна служба України. URL: https://dmsu.gov.ua/poslugi/ pasport-gromadyanina-ukrajni/id-vidacha-pasporta-gromadyanina-ukrajni-u-formi-kartkipo-dosyagnennyu-14-richnogo-viku-vpershe.html 


\section{Максименко О. Дитина як спеціальний суб'скт адміністративного права у процесі реалізації ювенальної політики України}

У статті розглянуто поняття адміністративного права України, проаналізовано наукові підходи до суб'єктів адміністративного права України. Охарактеризовано дитину як фізичну особу, яка не досягла 18 років. Наголошено на здатності дитини самостійно відповідати за свої протиправні вчинки після досягнення 16-річного віку. Згідно зі статтею 13 КУпАП України, до осіб віком 16-18 років, які вчинили адміністративні правопорушення, застосовуються відповідні заходи впливу, передбачені статтею 24-1 КУпАП: 1) зобов'язання публічно або в іншій формі попросити вибачення у потерпілого; 2) попередження; 3) догана або сувора догана; 4) передача неповнолітнього під нагляд батькам або особам, які їх замінюють, чи під нагляд педагогічному або трудовому колективу за їхньою згодою, а також окремим громадянам на їхнє прохання.

Зазначено, що розбудова ювенальної політики в Україні вимагає від органів державної влади запровадження новітніх способів задоволення інтересів дітей з обов'язковим урахуванням забезпечення їхніх найкращих інтересів. Досліджено особливості дитини як спеціального суб'єкта адміністративного права в процесі реалізації ювенальної політики України. Доведено, що обов'язковою умовою визнання фізичної особи суб'єктом адміністративного права $€$ наявність у неї елементів адміністративної правосуб'єктності. У адміністративному праві України варто розглядати правосуб'єктність із елементами правоздатності, дієздатності та деліктоздатності. Автором визначено основи ювенальної політики України та правового статусу дитини в адміністративному праві. Проаналізовано зміст Національної стратегії реформування системи юстиції щодо дітей на період до 2023 року. Визначено недоліки адміністративного законодавства щодо захисту прав дитини та розглянуто пропозиції з його удосконалення. Аргументоване авторське визначення дитини як спеціального суб'єкта адміністративного права України в процесі реалізації ювенальної політики. Визначено, що дитина є суб'єктом адміністративного права як фізична осудна особа, яка є носієм прав і обов'язків перед державою, а також до неї як до громадянина держава має низку прав та обов'язків.

Ключові слова: адміністративне право України, законодавство, суб'єкт, спеціальний суб'єкт, дитина, адміністративні стягнення, ювенальна політика.

Maksymenko $O$. The child as a special subject of administrative law in the process of implementation of the juvenile policy of Ukraine

The article considers the concept of administrative law of Ukraine, analyzes scientific approaches to the subjects of administrative law of Ukraine. The child was described as an individual under 18 years of age. Emphasis is placed on the child's ability to be held accountable for his or her wrongdoing after the age of 16. According to Article 13 of the Code of Administrative Offenses of Ukraine, persons aged 16-18 who have committed administrative offenses are subject to appropriate measures of influence provided for in Article 24-1 of the Code of Administrative Offenses: 1) the obligation to publicly or otherwise apologize to the victim; 2) warning; 3 ) reprimand or severe reprimand; 4) transfer of a minor under the supervision of parents or persons replacing them, or under the supervision of the teaching or labor collective with their consent, as well as individual citizens at their request. It is noted that the development of juvenile policy in Ukraine requires public authorities to introduce the latest ways to meet the interests of children, with due regard for their best interests. The peculiarities of the child as a special subject of administrative law in the process of implementation of the juvenile policy of Ukraine are studied. It is proved that the obligatory condition of recognition of a natural person as a subject of administrative law is the presence of elements of administrative legal personality. In the administrative law of Ukraine it is necessary to consider legal personality with elements of legal capacity, legal capacity and tort. The author identifies the basics of juvenile policy of Ukraine and the legal status of the child in administrative law. The content of the National Strategy for Reforming the Justice System for Children for the period up to 2023 is analyzed. The shortcomings of 
the Administrative legislation on the protection of the rights of the child are identified and proposals for its improvement are considered. The author's definition of a child as a special subject of administrative law of Ukraine in the process of implementing juvenile policy is argued. It is defined that a child is a subject of administrative law, as a natural sane person who is a holder of rights and obligations to the state, as well as to him as a citizen, the state has a number of rights and responsibilities.

Key words: administrative law of Ukraine, legislation, subject, special subject, child, administrative penalties, juvenile policy. 